\title{
Effect of intrahospital growth rate on somatometric measurements at 2 years old in children with a birth weight of less than 1500 grams
}

\author{
Salvador Piris Borregas, B.S. ${ }^{a}$, María J. Torres Valdivieso, M.D. ${ }^{a}$, \\ Cristina Martín-Arriscado Arroba, graduate ${ }^{b}$, María T. Moral Pumarega, M.D. ${ }^{a}$, \\ José Beceiro Mosquera, M.D. ${ }^{c}$ and Carmen R. Pallás Alonso, M.D. ${ }^{a}$
}

\begin{abstract}
Objective. To determine the association between intrahospital growth rate (GR) and breast milk fortification and somatometry, and risk for death after discharge or severe disability at 2 years of corrected age (CA).

Population and method. Retrospective analysis of GR and subsequent course. Infants born in the 1990-2015 period with a birth weight $<1500 \mathrm{~g}$ were included. Infants with diseases affecting growth were excluded. An overall cohort and 2 sub-cohorts were studied: infants born in the 1990-2001 period (without fortification) and 2002-2015 period (with fortification). The GR was estimated and deemed adequate if $>12 \mathrm{~g} / \mathrm{kg} /$ day.
\end{abstract}

a. Department of Neonatology, Hospital Universitario 12 de Octubre, Institute of Biomedical Research i+12, Universidad Complutense de Madrid, Madrid, Spain.

b. Institute of Epidemiology of Hospital Universitario 12 de Octubre, Madrid, Spain.

c. Department of Neonatology, Hospital Universitario Príncipe de Asturias, Madrid, Spain.

E-mail address: Salvador Piris Borregas, B.S.: salvador.piris@ salud.madrid.org

Funding:

None.

Conflict of interest:

None.

Received: 11-13-2020

Accepted: 5-10-2021

\section{INTRODUCTION}

In spite of the reduction in major morbidities affecting preterm newborn infants, ${ }^{1}$ postnatal growth restriction is still one of the main problems to be resolved in neonatal care units. ${ }^{2,3}$ Up to $50 \%$ of very low birth weight (VLBW) infants, but who have an adequate weight for their gestational age, are discharged with a weight percentile below the $10^{\text {th }}$ percentile (Pc10) for their postmenstrual age. ${ }^{4}$ The long term effects of such scarce intrahospital weight gain on the risk for death or severe disability and on the somatometric measurements of the preterm infant during their breastfeeding period are known. ${ }^{5-7}$ Several strategies, including breast milk fortification and donated milk, have been introduced in nutritional management for the purpose of reaching an adequate growth rate (GR) during hospitalization of VLBW infants. A positive effect on growth has been demonstrated during hospitalization, but the impact of these strategies beyond the neonatal period is still unknown.

The early detection of postnatal restriction is a priority. Instruments are required to monitor preterm infants' growth. GR is considered an indicator of quality in neonatal care units. ${ }^{8}$ Different mathematical formulas have been proposed, but with little agreement in terms of predictive ability of mortality after discharge or severe disability. ${ }^{9-13}$ Gradually, the use of formulas has extended, like the one proposed by Fenton, ${ }^{14}$ which simplify the estimation and use mean GR in a 
specific period of time. There is not enough information about the predictive ability of these simplified formulas.

The primary objective of this study was to determine if there is an association between mean intrahospital GR of VLBW infants, as estimated with the Fenton formula, and somatometric measurements at 2 years old of corrected age (CA). The secondary objectives were to determine if there is an association between mean intrahospital GR and the probability of death after discharge or severe disability at 2 years old, as well as to study the effect of introducing routine breast milk fortification on somatometric measurements and the risk for death or severe disability.

\section{POPULATION AND METHOD}

The study was conducted at a level IIIC neonatal care unit that provides follow-up care to VLBW infants up to 7 years old. A retrospective, cohort study was done for the 1990-2015 period. The study included children with a birth weight $\leq 1500 \mathrm{~g}$ in the 1990-2015 period. Children with major malformations or genetic disorders manifested in the prenatal or neonatal period and those who did not receive complete followup were excluded.

Two cohorts were established: the 1990-2001 cohort, who did not received fortification, and the 2002-2015 cohort, who received fortification. The nutritional strategy implemented in the area was the standard addition of fortificants to breast milk (from the mother or a donor) given to all preterm infants with a birth weight of less than $1500 \mathrm{~g}$ once an enteral volume of $80 \mathrm{~mL} / \mathrm{kg} /$ day was achieved, which entailed a protein intake between 3.3 and $3.8 \mathrm{~g} / \mathrm{kg} /$ day once an enteral intake between 150 and $175 \mathrm{~mL} / \mathrm{kg} /$ day was achieved. In addition, as of 2011, selective fortification was started when, besides reaching exclusive enteral intake and administering standard fortification, children had blood urea levels $\leq 19 \mathrm{mg} / \mathrm{dL}$, which implied a total protein intake between 3.5 and $4.2 \mathrm{~g} / \mathrm{kg} /$ day. During the study period, most children $(>80 \%)$ received their mother's own milk, at least during part of their hospitalization. Since 2008, practically $100 \%$ of children received their mother's own milk, donated milk, or both.

\section{Definition of variables}

The study dependent variable, mean intrahospital GR, was estimated using the Fenton formula:
Mean GR $=([$ weight at discharge $(\mathrm{g})-$ birth weight $(\mathrm{g})] /$ mean weight $(\mathrm{kg})) /$ length of stay (days); where mean weight $=$ (weight at discharge [g] + birth weight $[\mathrm{g}] / 2$ ).

The result of mean GR was expressed as $\mathrm{g} / \mathrm{kg} /$ day. Based on the quality criteria published in 2014 for neonatal care units, ${ }^{7}$ a mean GR was considered adequate if equal to or higher than $12 \mathrm{~g} / \mathrm{kg} /$ day.

The variable, study result, derives from the somatometric measurements at 2 years old (weight, height, and head circumference). In addition, a composite variable was developed for children follow-up, called "death after discharge or severe disability", and which was created in the presence of any of the following events up to 2 years old of CA: death after discharge, visual acuity below 10/100 in the better eye, bilateral hearing impairment without reaching useful hearing with amplification (in general, greater than $90 \mathrm{~dB}$ ), cerebral palsy equal to or greater than level 3 out of 5 in the Gross Motor Function Classification System, ${ }^{15}$ or Bayley II Index ${ }^{16}$ below 55, Bayley III Inde $x^{17}$ below 65 , or a clinical impression of severe neurodevelopmental disorder according to a neonatologist with experience in follow-up of preterm infants. Catchup was defined as reaching the $10^{\text {th }}$ percentile or higher for the corresponding somatometric parameter (weight, height or head circumference). All data were collected from the follow-up medical record.

The following variables for the intrahospital period were considered: gestational age at birth, sex, ductus surgical repair, presence of pneumothorax, total days of intubation and oxygen, total length of stay in days, bronchopulmonary dysplasia if oxygen was required at 36 weeks of postmenstrual age, and severe retinopathy if greater than grade 3 or requiring laser therapy. Severe brain injury was also considered if the patient had grade 3 or higher intraventricular hemorrhage, grade 3 ventriculomegaly or grade 3 parenchymal lesion. ${ }^{18}$

\section{Statistical analysis}

No formal estimation of the sample size was made because it was decided to include all patients who met the inclusion criteria in each cohort. Cohorts were compared using non-parametric tests (Mann-Whitney U test, Wilcoxon's test or Student's $t$ test), and the $\chi^{2}$ test, or Fisher's exact test, depending on variables' nature. The assessment of factors for the 
association between somatometric measurements at 2 years old of CA and mean GR was done based on a logistic regression stratified for GA, represented by the odds ratio or Wald $95 \%$ confidence interval. The level of significance was set at $5 \%$.

\section{Ethical aspects}

The study was assessed and approved by the Research Ethics Committee of Hospital Universitario 12 de Octubre. The General Data Protection Regulation and the principles of the Declaration of Helsinki were observed throughout the process.

\section{RESULTS}

A total of 2084 preterm newborn infants with a birth weight $\leq 1500 \mathrm{~g}$ were admitted to the neonatal care unit in the 1990-2015 period. Figure 1 shows the flow chart after applying the exclusion criteria. In the 1990-2001 cohort, the final sample was made up of 478 patients, whereas the 2002-2015 cohort included 716 patients. Table 1 shows the general characteristics of both cohorts and the comparative analysis between them. It is worth noting that, in the 2002-2015 cohort, mean gestational age was significantly younger ( 27.99 weeks \pm 2.01 versus $28.37 \pm 1.98, p<0.01$ ).

Table 2 shows the results of compared somatometric measurements of children in the overall cohort and the 2 sub-cohorts at 2 years old of CA based on whether they had reached or not an adequate intrahospital GR. When patients achieved an adequate mean GR in the hospital period, compared to those who did not, their median weight at 2 years old of CA was significantly higher in the overall cohort $(11400 \mathrm{~g}$ [10 300-12 500] versus $11000 \mathrm{~g}$ [10 000-12 140], $p=0.02)$ and in the cohort with fortification (11 $420 \mathrm{~g}$ [10 400-12 500] versus $11155 \mathrm{~g}$ [10 10012 090], $p=0.04)$. However, in the case of height, only in the 2002-2015 cohort, children who achieved an adequate mean GR had a taller mean height at 2 years old of CA $(86.42 \pm 4.03 \mathrm{~cm}$ versus $85.56 \pm 4.01, p<0.02)$.

FIGURE 1. Flow chart and volume of patients after the implementation of exclusion criteria

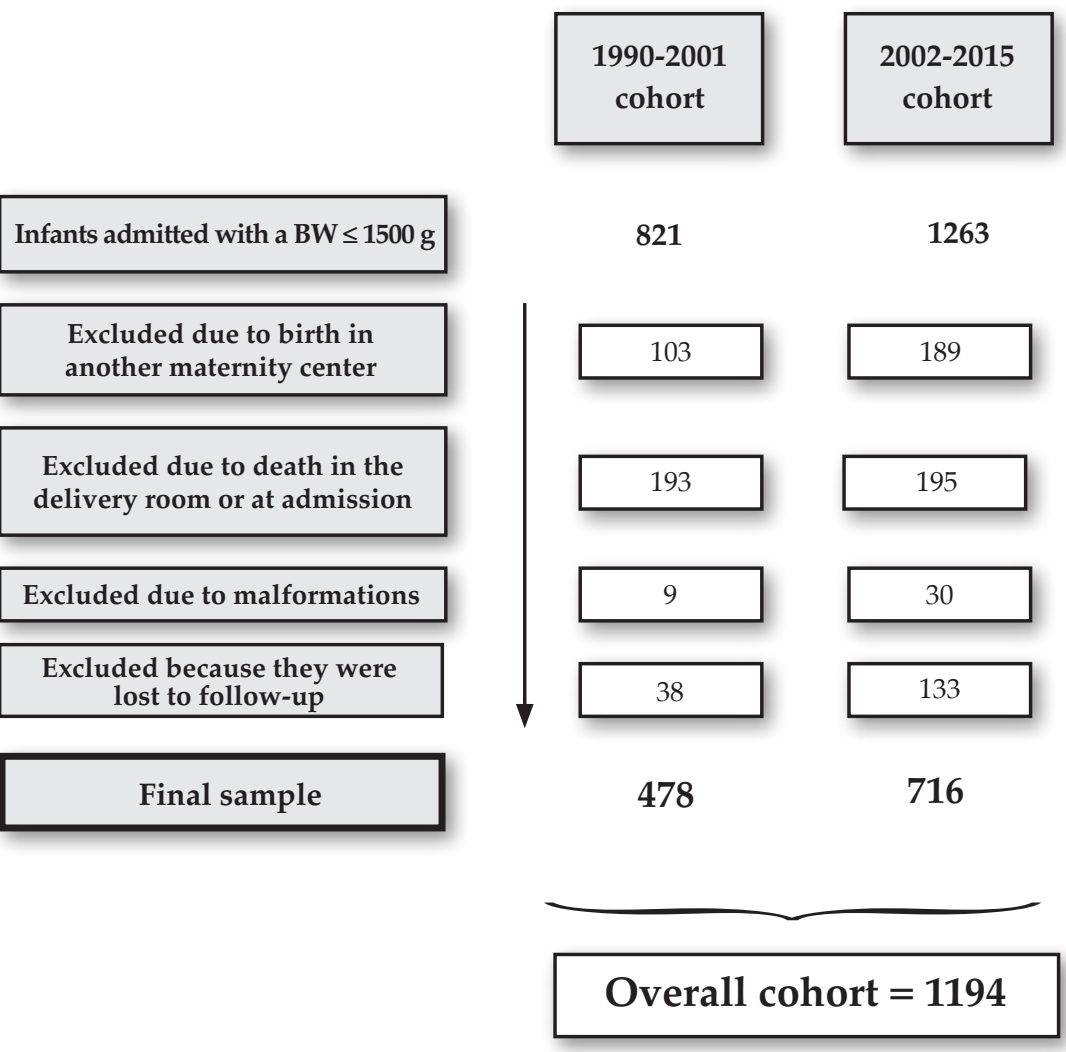

BW: birth weight. 
A post hoc analysis was done of the number of preterm newborn infants with somatometric percentiles below the Pc10 at birth who caughtup at 2 years old of CA based on their mean intrahospital GR. All results of this analysis are shown in Table 3. In relation to these, it is worth noting that, in the overall cohort, the percentage of newborn infants with a low birth weight for gestational age who reached the Pc10 for weight at 2 years old of CA was higher when the mean intrahospital GR was adequate compared to inadequate $(62.50 \%$ versus $34.69 \%, p=0.02)$. The same was observed with the assessment of the percentage of newborn infants who, being below the Pc10 for head circumference at birth caughtup at 2 years old of CA $(79.16 \%$ versus $56.98 \%$, $p<0.01)$. When sub-cohorts were analyzed as well, results showed the same behavior for weight, height, and head circumference in the 2002-2015 cohort, but no significant differences were noted in the 1990-2001 cohort.

TABLE 1. Description of the sample and comparisons between cohorts

\begin{tabular}{|c|c|c|c|c|}
\hline Variables & $\begin{array}{l}\text { Overall cohort } \\
\qquad N=1194\end{array}$ & $\begin{array}{c}1990-2001 \text { cohort } \\
\mathrm{N}=478\end{array}$ & $\begin{array}{c}2002-2015 \text { cohort } \\
\text { N }=716\end{array}$ & $p$ value \\
\hline Female sex $(\%)$ & $576(48.24)$ & $234(48.95)$ & $342(47.77)$ & 0.72 \\
\hline GA in weeks (mean/SD) & $28.16(1.99)$ & $28.42(1.95)$ & $27.99(2.00)$ & $<0.01$ \\
\hline Birth weight (g) (median/IQR) & $1070.00(855.00-1270.00)$ & $1100.00(900.00-1278.00)$ & $1053.00(840.00-1264.00)$ & 0.07 \\
\hline Birth length $(\mathrm{cm})($ mean $/ \mathrm{SD})$ & $36.58(3.21)$ & $36.73(3.12)$ & $36.48(3.26)$ & 0.23 \\
\hline Birth HC (cm) (mean/SD) & $26.14(2.23)$ & $26.24(2.27)$ & $26.08(2.21)$ & 0.14 \\
\hline Severe ROP $(\%)$ & $41(3.43)$ & $22(4.60)$ & $19(2.65)$ & 0.07 \\
\hline $\mathrm{O}_{2}$ at 36 weeks $(\%)$ & $202(17.34)$ & $82(18.22)$ & $120(16.78)$ & 0.52 \\
\hline PDA treated with surgery $(\%)$ & $88(8.72)$ & $25(5.57)$ & $63(11.25)$ & $<0.01$ \\
\hline Severe brain injury $(\%)$ & $137(11.47)$ & $55(11.29)$ & $82(11.34)$ & 0.99 \\
\hline NEC treated with surgery $(\%)$ & $15(1.58)$ & $4(0.90)$ & $11(2.18)$ & 0.12 \\
\hline Pneumothorax $(\%)$ & $36(3.78)$ & $16(3.57)$ & $20(3.96)$ & 0.86 \\
\hline Days with intubation (mean/SD) & $1.00(0.00-7.00)$ & $3.00(1.00-9.00)$ & $1.00(0.00-5.00)$ & $<0.01$ \\
\hline Days with oxygen therapy (mean/SD) & $12.50(1.00-49.00)$ & $19.00(3.00-52.00)$ & $10.00(1.00-48.00)$ & $<0.01$ \\
\hline Length of stay in days (mean/SD) & $67.00(51.00-91.00)$ & $70.00(53.00-93.00)$ & $65.50(49.00-89.00)$ & 0.09 \\
\hline
\end{tabular}

GA: gestational age; SD: standard deviation; $\mathrm{HC}$ : head circumference; ROP: retinopathy of prematurity; $\mathrm{O}_{2}$ : oxygen; PDA: patent ductus arteriosus; NEC: necrotizing enterocolitis; IQR: interquartile range.

TABLE 2. Comparison of anthropometric measures at 2 years old of corrected age considering an adequate or inadequate mean intrahospital growth rate in the overall cohort and the different cohorts of nutritional strategies. It also shows the comparison of a growth rate model adjusted for gestational age

\begin{tabular}{|c|c|c|c|c|c|c|c|c|c|c|c|c|}
\hline & \multicolumn{4}{|c|}{$\begin{array}{l}\text { Overall cohort } \\
\qquad N=1194\end{array}$} & \multicolumn{4}{|c|}{$\begin{array}{c}1990-2002 \text { cohort } \\
\mathrm{N}=478\end{array}$} & \multicolumn{4}{|c|}{$\begin{array}{c}2002-2015 \text { cohort } \\
N=716\end{array}$} \\
\hline & $\begin{array}{c}\text { Adequate } \\
\text { GR } \\
\mathrm{N}=\mathbf{1 7 7}\end{array}$ & $\begin{array}{c}\text { Inadequate } \\
\text { GR } \\
\mathrm{N}=1017\end{array}$ & $\begin{array}{c}P \\
\text { value }\end{array}$ & $\begin{array}{c}P \\
\text { adjusted } \\
\text { for GA }\end{array}$ & $\begin{array}{l}\text { Adequate } \\
\text { GR } \\
N=29\end{array}$ & $\begin{array}{c}\text { Inadequate } \\
\text { GR } \\
N=449\end{array}$ & $\begin{array}{c}P \\
\text { value }\end{array}$ & $\begin{array}{c}P \\
\text { adjusted } \\
\text { for GA }\end{array}$ & $\begin{array}{c}\text { Adequate } \\
\text { GR } \\
\mathrm{N}=148\end{array}$ & $\begin{array}{c}\text { Inadequate } \\
\text { GR } \\
N=568\end{array}$ & $\begin{array}{l}\text { e } P \\
\text { value }\end{array}$ & $\begin{array}{c}P \\
\text { adjusted } \\
\text { for GA }\end{array}$ \\
\hline $\begin{array}{l}\text { Weight (g) } \\
\text { (median/IQR) }\end{array}$ & $\begin{array}{c}11400 \\
(10300- \\
12500)\end{array}$ & $\begin{array}{r}11000 \\
(10000- \\
12140)\end{array}$ & 0.02 & 0.03 & $\begin{array}{l}11300 \\
(9800- \\
12200)\end{array}$ & $\begin{array}{l}11000 \\
(9960- \\
12200)\end{array}$ & 0.92 & 0.92 & $\begin{array}{c}11420 \\
(10400- \\
12500)\end{array}$ & $\begin{array}{r}11155 \\
(10100- \\
12090)\end{array}$ & 0.04 & 0.049 \\
\hline $\begin{array}{l}\text { Height }(\mathrm{cm}) \\
(\text { mean } / \mathrm{SD})\end{array}$ & $86.16(3.94)$ & $85.26(3.89)$ & 0.02 & $<0.01$ & $84.90(3.21)$ & 84.88 (3.69) & 0.90 & 0.90 & $86.42(4.03)$ & $85.56(4.01)$ & 0.06 & 0.02 \\
\hline $\begin{array}{l}\text { Head } \\
\text { circumference } \\
(\mathrm{cm})(\text { mean } / \mathrm{SD})\end{array}$ & $48.20(1.69)$ & 48.01 (1.92) & 0.33 & 0.82 & 48.07 (1.54) & $48.04(1.90)$ & 0.67 & 0.61 & 48.23 (1.73) & 47.99 (1.93) & 0.16 & 0.63 \\
\hline $\begin{array}{l}\text { Mean GA } \\
\text { (semanas) } \\
\text { (mean/SD) }\end{array}$ & $29.01(1.63)$ & $28.02(2.01)$ & $<0.01$ & & $29.69(1.31)$ & $28.33(1.95)$ & $<0.01$ & & $28.87(1.66)$ & $27.77(2.02)$ & $<0$ & .01 \\
\hline
\end{tabular}

VC: velocidad de crecimiento; IC: rango intercuartílico; DE: desviación estándar; EG: edad gestacional. 
Table 4 details the number of children who died after discharge compared to those who developed severe disability, but did not die. These data are shown based on the independent variable GR and stratified for the nutritional subcohorts assessed in this study. In addition, Table 5 shows the comparison of the risk for death after discharge or severe disability at 2 years old of CA considering mean intrahospital GR. No significant differences were observed in the overall cohort or the sub-cohorts.

\section{DISCUSSION}

This study shows how, in recent decades, the population of VLBW infants with an adequate mean intrahospital GR, as estimated based on

TABLE 3. Comparison of the proportion of preterm newborn infants with a weight, height, and head circumference percentile at birth below the 10th percentile who caught-up at 2 years old of corrected age based on their adequate or inadequate mean intrahospital growth rate

\begin{tabular}{|c|c|c|c|c|}
\hline & & Adequate GR & Inadequate GR & $p$ value \\
\hline \multirow[t]{3}{*}{$\begin{array}{l}\text { Patients (n) with a weight percentile }<10 \text { at birth } \\
\text { who caught-up their weight at } 2 \text { years old of CA }(\%)\end{array}$} & Overall cohort & $\begin{array}{l}30 / 48 \\
(62.5)\end{array}$ & $\begin{array}{l}34 / 98 \\
(34.69)\end{array}$ & 0.02 \\
\hline & 1990-2001 cohort & $\begin{array}{c}3 / 7 \\
(42.85)\end{array}$ & $\begin{array}{l}14 / 44 \\
(31.81)\end{array}$ & 0.67 \\
\hline & 2002-2015 cohort & $\begin{array}{l}27 / 41 \\
(65.85)\end{array}$ & $\begin{array}{l}20 / 54 \\
(37.03)\end{array}$ & $<0.01$ \\
\hline \multirow[t]{3}{*}{$\begin{array}{l}\text { Patients (n) with a height percentile }<10 \text { at birth } \\
\text { who caught-up their height at } 2 \text { years old of CA }(\%)\end{array}$} & Overall cohort & $\begin{array}{l}34 / 48 \\
(70.83)\end{array}$ & $\begin{array}{l}61 / 98 \\
(62.24)\end{array}$ & 0.35 \\
\hline & 1990-2001 cohort & $\begin{array}{c}4 / 7 \\
(57.14)\end{array}$ & $\begin{array}{l}27 / 44 \\
(61.36)\end{array}$ & 1 \\
\hline & 2002-2015 cohort & $\begin{array}{l}30 / 41 \\
(73.17)\end{array}$ & $\begin{array}{l}34 / 54 \\
(62.96)\end{array}$ & 0.29 \\
\hline \multirow[t]{3}{*}{$\begin{array}{l}\text { Patients (n) with a } \mathrm{HC} \text { percentile }<10 \text { at birth } \\
\text { who caught-up their } \mathrm{HC} \text { at } 2 \text { years old of CA }(\%)\end{array}$} & Overall cohort & $\begin{array}{l}38 / 48 \\
(79.16)\end{array}$ & $\begin{array}{l}53 / 93 \\
(56.98)\end{array}$ & $<0.01$ \\
\hline & 1990-2001 cohort & $\begin{array}{c}5 / 7 \\
(71.42)\end{array}$ & $\begin{array}{l}23 / 41 \\
(56.09)\end{array}$ & 0.68 \\
\hline & 2002-2015 cohort & $\begin{array}{l}33 / 41 \\
(80.48)\end{array}$ & $\begin{array}{l}30 / 52 \\
(57.69)\end{array}$ & 0.01 \\
\hline
\end{tabular}

GR: growth rate; CA: corrected age; HC: head circumference.

TABLE 4. Proportion of infants who died and who had severe disability at 2 years old of corrected age based on mean intrahospital growth rate and studied nutritional cohorts

\begin{tabular}{|c|c|c|c|c|c|c|}
\hline & \multicolumn{2}{|c|}{ Overall cohort } & \multicolumn{2}{|c|}{ Adequate GR } & \multicolumn{2}{|c|}{ Inadequate GR } \\
\hline & $\begin{array}{c}\text { Number of } \\
\text { deceased } \\
\text { infants/Total } \mathrm{N} \\
(\%)\end{array}$ & $\begin{array}{c}\text { Number of infants } \\
\text { with severe } \\
\text { disability/Total N } \\
(\%)\end{array}$ & $\begin{array}{c}\text { Number } \\
\text { of deceased } \\
\text { Infants/Total } \mathrm{N} \\
(\%)\end{array}$ & $\begin{array}{c}\text { Number of infants } \\
\text { with severe } \\
\text { disability/Total N } \\
(\%)\end{array}$ & $\begin{array}{c}\text { Number } \\
\text { of deceased } \\
\text { Infants/Total N } \\
(\%)\end{array}$ & $\begin{array}{c}\text { Number of infants } \\
\text { with severe } \\
\text { disability/Total N } \\
(\%)\end{array}$ \\
\hline Overall cohort & $\begin{array}{c}111 / 1194 \\
(9.29)\end{array}$ & $\begin{array}{c}76 / 1194 \\
(6.3)\end{array}$ & $\begin{array}{c}16 / 177 \\
(9.03)\end{array}$ & $\begin{array}{l}4 / 177 \\
(2.25)\end{array}$ & $\begin{array}{c}95 / 1017 \\
(9.34)\end{array}$ & $\begin{array}{c}72 / 1017 \\
(7.07)\end{array}$ \\
\hline 1990-2002 cohort & $\begin{array}{c}43 / 478 \\
(9)\end{array}$ & $\begin{array}{c}32 / 478 \\
(6.69)\end{array}$ & $\begin{array}{c}0 / 29 \\
(0)\end{array}$ & $\begin{array}{c}3 / 29 \\
(10.34)\end{array}$ & $\begin{array}{c}43 / 449 \\
(9.57)\end{array}$ & $\begin{array}{c}29 / 449 \\
(6.45)\end{array}$ \\
\hline 2002-2015 cohort & $\begin{array}{c}68 / 716 \\
(9.49)\end{array}$ & $\begin{array}{c}44 / 716 \\
(6.14)\end{array}$ & $\begin{array}{l}16 / 148 \\
(10.81)\end{array}$ & $\begin{array}{l}1 / 148 \\
(0.67)\end{array}$ & $\begin{array}{c}52 / 568 \\
(9.15)\end{array}$ & $\begin{array}{c}43 / 568 \\
(7.57)\end{array}$ \\
\hline
\end{tabular}

GR: growth rate. 
the Fenton formula, reached a higher weight at 2 years old of CA. In the cohort with breast milk fortification, children with an adequate mean intrahospital GR also reached a higher height at 2 years old of CA; this cohort had a significantly younger mean gestational age. Such younger mean gestational age in the 2002-2015 cohort may be explained by a greater patient complexity resulting from an increasingly more active care at the unit from working with smaller preterm infants. Also, a higher number of children whose weight and head circumference were below the Pc10 recovered to normal percentiles at 2 years old of CA when mean intrahospital GR was adequate, both in the overall cohort and in the cohort with fortification.

Only one study has explored the impact of intrahospital GR on anthropometric measures in early childhood. That study was conducted by Ehrenkranz et al. ${ }^{2}$ and included 495 preterm newborn infants with a birth weight between $501 \mathrm{~g}$ and $1000 \mathrm{~g}$. They objectively established that the percentage of children below the Pc10 for weight and height at 18 months old of CA was significantly lower as GR increased in the neonatal period. These results are consistent with those of our study.

In relation to the impact of breast milk protein fortification on anthropometric measures in early childhood, some studies have demonstrated that this nutritional strategy allows a greater intrahospital gain in terms of weight, ${ }^{19}$ height, ${ }^{20}$ and head circumference ${ }^{21}$ until 40 weeks of postmenstrual age. Our findings demonstrate that the cohort with fortification reached a higher height at 2 years old of CA and that a higher percentage of preterm newborn infants caught-up in terms of head circumference. Some studies have compared different levels of protein fortification in the long term. Dogra et al., ${ }^{21}$ did not find a significant improvement in anthropometric measures at 12-18 months old when comparing fortification with $1 \mathrm{~g}$ of protein $/ 100 \mathrm{~mL}$ to $0.4 \mathrm{~g} / 100 \mathrm{~mL}$. However, Mariani et al., ${ }^{22}$ compared 2 protein fortification regimens at 2 neonatal units; protein fortification with $3.5 \mathrm{~g} / \mathrm{kg} /$ day versus $4.8 \mathrm{~g} / \mathrm{kg} /$ day in a population of newborn infants with a birth weight $\leq 1500 \mathrm{~g}$, and found a greater head circumference and height at 12 and 24 months old in the cohort that received fortification. In addition, some studies support the fact that strategies such as fortification have allowed to reconcile 2 current challenges observed in neonatal care units: increasing the GR of preterm newborn infants without affecting breastfeeding rates. ${ }^{23}$

A fair amount of evidence supports the association between an adequate GR and a lower risk for death after discharge or severe disability. Several studies and systematic reviews have demonstrated a positive association between an adequate weight gain and better cognitive results in an age range from 12 months to 19 years.,24-27 Our study did not find a significant association between an adequate mean intrahospital GR and a lower risk for death after discharge or severe disability at 2 years old of CA. Most likely, the low frequency of death after discharge and severe disability prevents the possibility of establishing statistical significance. In addition,

TABLE 5. Comparison of risk for death after discharge or severe disability at 2 years old of corrected age considering the mean intrahospital growth rate in the overall cohort and the nutritional cohorts. It also shows the comparison of a growth rate adjusted for gestational age

\begin{tabular}{|c|c|c|c|c|}
\hline & $\begin{array}{c}\text { Adequate GR } \\
\text { Number of deceased } \\
\text { infants or infants with } \\
\text { severe disability / N } \\
\text { with adequate GR }(\%)\end{array}$ & $\begin{array}{c}\text { Inadequate GR } \\
\text { Number of deceased } \\
\text { infants or infants } \\
\text { with severe disability / N } \\
\text { with inadequate GR }(\%)\end{array}$ & OR $(95 \%$ CI $)$ & $\begin{array}{c}\text { OR (95\% CI) } \\
\text { adjusted for GA }\end{array}$ \\
\hline Overall cohort & $\begin{array}{l}20 / 177 \\
(11.29)\end{array}$ & $\begin{array}{c}167 / 1017 \\
(16.42)\end{array}$ & $0.65(0.38-1.04)$ & $0.79(0.47-1.12)$ \\
\hline 1990-2001 cohort & $\begin{array}{c}3 / 29 \\
(10.34)\end{array}$ & $\begin{array}{l}72 / 449 \\
(16.03)\end{array}$ & $0.60(0.14-1.77)$ & $0.84(0.19-2.57)$ \\
\hline 2002-2015 cohort & $\begin{array}{l}17 / 148 \\
(11.48)\end{array}$ & $\begin{array}{c}95 / 568 \\
(16.72)\end{array}$ & $0.65(0.36-1.09)$ & $0.80(0.44-1.39)$ \\
\hline
\end{tabular}

GR: growth rate; GA: gestational age; OR: odds ratio; CI: confidence interval. 
some other clinical aspects of the intrahospital period, such as sepsis, nosocomial infection or delayed intrauterine growth retardation, as well as socioeconomic factors present in the course between hospital discharge and 2 years of life may have an effect on said association, but were not analyzed in this study. ${ }^{28,29}$

This is the first study to explore the relationship between mean intrahospital GR as estimated based on simplified formulas and somatometric measurements beyond the neonatal period. The limitations of this study include the little presence of the event death after discharge or severe disability in this sample because it was distributed into groups, and a larger sample size would be required to study its relationship with GR. There may be other modifications in clinical practice that may or may not be related to the association between GR and somatometric measurements and the risk for death after discharge or severe disability at 2 years old of $\mathrm{CA}$ and that may affect results, e.g., the opening of a donated breast and pasteurized milk bank in 2008. In light of the results described here, it may be concluded that mean intrahospital GR improved somatometric measurements at 2 years old. In addition, in the studied population, breast milk fortification was related to a higher height and a significant greater percentage of VLBW infants who caught-up in terms of head circumference during early childhood.

\section{REFERENCES}

1. Richter L, Ting J, Muraca G, Boutin A, et al. Temporal Trends in Preterm Birth, Neonatal Mortality, and Neonatal Morbidity Following Spontaneous and Clinician-Initiated Delivery in Canada, 2009-2016. J Obstet Gynaecol Can. 2019.

2. Ehrenkranz RA, Dusick AM, Vohr BR, Wright LL, et al. Growth in the neonatal intensive care unit influences neurodevelopmental and growth outcomes of extremely low birth weight infants. Pediatrics. 2006; 117(4):1253-61.

3. Cooke RJ, Ainsworth SB, Fenton AC. Postnatal growth retardation: a universal problem in preterm infants. Arch Dis Child Fetal Neonatal Ed. 2004; 89(5):428-30.

4. Horbar J, Ehrenkranz R, Badger G, Edwards E, et al. Weight growth velocity and postnatal growth failure in infants 501 to 1500 grams: 2000-2013. Pediatrics. 2015; 136(1):e84-92.

5. Shah PS, Wong KY, Merko S, Bishara R, et al. Postnatal growth failure in preterm infants: ascertainment and relation tolong-term outcome. JPerinat Med.2006;34(6):4849.

6. Franz AR, Pohlandt F, Bode H, Mihatsch W, et al. Intrauterine, early neonatal, and postdischarge growth and neurodevelopmental outcome at 5.4 years in extremely preterminfants after intensive neonatal nutritional support. Pediatrics. 2009; 123(1):e101-9.

7. Sammallahti S, Pyhälä R, Lahti M, Lahti J, et al. Infant growth after preterm birth and neurocognitive abilities in young adulthood. J Pediatr. 2014; 165(6):1109-15.e3.

8. Profit M, Kowalkowski J, Zupancic JA, Pietz K, et al. Babymonitor: a composite indicator of NICU quality. Pediatrics. 2014; 134(1):74-82.

9. Fenton T, Chan H, Madhu A, Griffin I, et al. Preterm infant growth velocity calculations: a systematic review. Pediatrics. 2017; 139(3):e20162045.

10. Fenton T, Anderson D, Groh-Wargo S, Hoyos A, et al. An Attempt toStandardize the Calculation of Growth Velocity of Preterm Infants-Evaluation of Practical BedsideMethods. J Pediatr. 2018; 196:77-83.

11. Briend A, Maire B, Fontaine O, Garenne M. Mid-upper arm circumference and weight-for-height to identify high-risk malnourisher under-five children. Matern Child Nutr. 2012; 8(1):130-3.

12. O'Neill SM, Fitzgerald A, Briend A, Van den Broeck J. Child mortality as predicted by nutritional status and recent weight velocity in children under two in rural Africa. J Nutr. 2012; 142(3):520-5.

13. Chen LC, Chowdhury A, Huffman SL. Anthropometric assessment of energy-protein malnutrition and subsequent risk of mortality among preschool aged children. Am J Clin Nutr. 1980; 33(8):1836-45.

14. Fenton T, Nasser R, Eliasziw M, Kim J, et al. Validating the weight gain of preterm infants between the reference growth curve of the fetus and the term infants. BMC Pediatr. 2013; 13:92.

15. Park E. Stability of the gross motor function classification system in children with cerebral palsy for two years. BMC Neurol. 2020; 20(1):172.

16. Kilbride HW, Aylward GP, Doyle LW, Singer LT, Lantos J. Prognostic neurodevelopmental testing of preterm infants: do we need to change the paradigm? J Perinatol. 2017; 37(5):475-9.

17. Spencer-Smith M, Spittle A, Lee K, Doyle L, Anderson P. Bayley-III Cognitive and Language Scales in Preterm Children. Pediatrics. 2015; 135(5):e1258-65.

18. Maller V, Cohen H. Neonatal Head Ultrasound: A Review and Update-Part 1: Techniques and Evaluation of the Premature Neonate. Ultrasound Q. 2019; 35(3):202-11.

19. Moya F, Sisk PM, Walsh K, Berseth CL. A new liquid human milk fortifier and linear growth in preterm infants. Pediatrics. 2012; 130(4):e928-35.

20. Olsen IE, Harris CL, Lawson ML, Berseth CL. Higher protein intake improves length, not weight, z scores in preterm infants. J Pediatr Gastroenterol Nutr. 2014; 58(4):409-16.

21. Dogra S, Thakur A, Garg P, Kler N. Effect of differential enteral protein on growth and neurodevelopmentininfants $<1500 \mathrm{~g}$ : a randomized controlled trial. J Pediatr Gastroenterol Nutr. 2017; 64(5):e126-32.

22. Mariani E, Biasini A, Marvulli L, Maritini S, et al. Strategies of increased protein intake in ELBW infants fed by human milk lead to long term benefits. Front Public Health. 2018; 6:272.

23. Piris Borregas S, López Maestro M, Torres Valdivieso MJ, Martínez Ávila JC, et al. Improving nutritional practices in premature infants can increase their growth velocity and the breastfeeding rates. Acta Paediatr. 2017; 106(5):768-72.

24. Belfort MB, Rifas-Shiman SL, Sullivan T, Collins CT, et al. Infant growth before and after term: effects on neurodevelopment in preterm infants. Pediatrics. 2011; 128(4):899-906.

25. Latal-Hajnal B, von Siebenthal K, Kovari H, Bucher HU, Largo RH. Postnatal growth in VLBW infants: significant association with neurodevelopmental outcome. J Pediatr. 2003; 143(2):163-70. 
26. Claas MJ, de Vries LS, Koopman C, Uniken Venema MM, et al. Postnatal growth of preterm born children $</=750$ g at birth. Early Hum Dev. 2011; 87(7):495-507.

27. Ong K, Kennedy K, Castañeda-Gutiérrez E, Forsyth $\mathrm{S}$, et al. Postnatal growth in preterm infants and later health outcomes: a systematic review. Acta Pædiatr. 2015; 104(10):974-86.
28. Krebs N, Lozoff B, Georgieff M. Neurodevelopment: The Impact of Nutrition and Inflammation During Infancy in Low-Resource Settings Pediatrics. 2017; 139(Suppl 1):S50-8. 29. Zonneberg I, van DijK-Lokkart E, van den Dunjen F, Vermeulen F, van Weissenbruch M. Neurodevelopmental outcome at 2 years of age in preterm infants with late-onset sepsis. Eur J Pediatr. 2019; 178(5):673-80. 